\title{
PENINGKATAN KETERAMPILAN MENGAPRESIASIKAN NOVEL MELALUI PENDEKATAN KOOPERATIF TIP THINK PAIR SHARE SISWA KELAS IX SMPN 10 PAYAKUMBUH
}

\author{
Sufia Retti \\ STKIP Yayasan Abdi Pendidikan Payakumbuh \\ Retti_sufia@yahoo.com
}

\begin{abstract}
Abstrak: Penelitian ini dilatarbelakangi oleh rendahnya keterampilan siswa dalam mengapresiasi sastra. Hal ini terlihat pada nilai harian siswa yang berada di bawah kriteria ketuntasan minimum. Rendahnya keterampilan mengapresiasi novel tersebut berasal dari rendahnya minat baca siswa. Siswa perlu dihadapkan pada karya novel secara utuh tidak berupa sinopsis. Jenis penelitian ini adalah tindakan kelas. Penelitian dilaksanakan dalam dua siklus. Data penelitian diperoleh dalam bentuk data kualitatif dan data kuantitatif. Data kualitatif dikumpulkan melalui observasi, catatan lapangan dan angket. Data kuantitatif diperoleh melalui tes akhir siklus. Temuan penelitian menunjukkan bahwa pembelajaran mengapresiasikan novel siswa meningkat melalui pendekatan kooperatif tipe TPS. Peningkatan tersebut pada hasil tes siklus I dengan rata-rata 68,99 dan siklus II 79,22. Beberapa faktor yang menyebabkan terjadinya peningkatan tersebut diantaranya; pemilihan metode yang sesuai dengan materi dan karakteristik siswa, rencana dan tindakan guru yang tepat, dan memotivasi siswa sehingga bersemangat dan aktif dalam belajar.
\end{abstract}

Kata kunci; peningkatan, keterampilan, mengapresiasi novel, kooperatif

\section{PENDAHULUAN}

Dang berhadapan langsung dengan teks-teks sastra tidak lepas dari kegiatan membaca. Keberhasilan siswa dalam mengapresiasi sastra sangat ditentukan oleh kemauan dan kemampuan membaca siswa. Bahkan kemauan dan kemampuan membaca siswa akan mempengaruhi keluasan pandangan terhadap pemahaman dan pemaknaan yang lebih terhadap karya sastra. Oleh sebab itu rendahnya kemampuan mengapresia- sikan sastra berawal dari kemauan dan kemampuan membaca siswa yang rendah.

Berdasarkan pengamatan di lapangan, permasalahan pembelajaran mengapresiasi sastra di kelas IX SMPN 10 Payakumbuh khususnya apresiasi novel disebabkan kemauan dan kemampuan membaca siswa 
yang rendah. Kegiatan membaca belum dilakukan secara optimal menyebabkan siswa belum mampu mengapresiasi sastra dengan baik. Siswa belum dihadapkan pada teks novel yang sesungguhnya. Siswa hanya dihadapkan pada sinopsissinopsis novel. Sehingga dalam mengapresiasi novel siswa hanya melihat dari penggalan-penggalan novel. Selanjutnya minat dan motivasi siswa yang minim. Siswa beranggapan bahwa pembelajaran sastra tidak penting, siswa cendeung mendengar dan mencatat materi yang disampaikan guru. Kesempatan bertanya yang diberikan guru juga kurang direspon oleh siswa. Ketika aktivitas di dikusi siswa hanya jadi pendengar tanpa melibatkan diri secara aktif.

Proses pembelajaran memegang peranan penting untuk mengatasi permasalahan yang ada. Proses pembelajaran akan bermakna apabila guru mampu memilih metode pembelajaran yang sesuai dengan karakteristik siswanya. Metode pembelajaran harus menekankan pada aktivitas siswa dengan bimbingan guru. Siswa diarahkan untuk memiliki kemampuan belajar secara mandiri dan kelompok. Metode pembelajaran yang digunakan diharapkan juga mampu menunjang perkembangan fisik dan mental. Dengan demikian, metode pembelajaran kooperatif tipe think pair share diduga mampu mengatasi permasalahan dalam pembelajaran

\section{PENA LITERASI}

Jurnal Pendidikan Bahasa dan Sastra Indoniasia Volume $x$ Nomor $x$ April 2018

apresisasi novel siswa kelas IX SMPN 10 Payakumbuh.

Menurut Waluyo

(2002)

apresiasi sastra merupakan penghargaan terhadap karya sastra sebagai hasil pengenalan, pemahaman, penafsiran, penghayatan, dan penikmatan terhadap karya sastra tersebut yang didukung oleh kepekaan batin terhadap nilai-nilai yang terkandung dalam karya sastra. Menurut Wijaya (dalam Kurniawan, 2009) yang menyatakan bahwa apresisasi adalah penghargaan dan pemahaman terhadap suatu hasil seni dan budaya, termasuk karya satra. Efendi (dalam Aminuddin, 2009) mengungkapkan bahwa apresiasi sastra adalah kegiatan "menggauli" karya sastra secara sungguh-sungguh menumbuhkan pengertian dan penghargaan, kepekaan pikiran kritis dan kepekaan perasaan yang baik terhadap karya sastra.

Pembelajaran apresiasi sastra tidak akan terlepas dari kegiatan membaca. Kegiatan membaca merupakan prilaku aktif atau yang disebut dengan aktivitas yang dinamis. Apresiasi sastra berkaitan dengan penghargaan dan penilaian maka kegiatan yang paling fundamental dalam apresiasi karya sastra adalah pembacaan. Apresiasi sastra berkaitan dengan pembacaan terhadap karya sastra. Menurut Kurniawan (2009), langkah dasar seseorang untuk bisa mengapresiasi karya sastra adalah membaca yang merupakan kunci pokok dari apresiasi. 
e-ISSN : 2614-8226

Website : https://jurnal.umj.ac.id/index.php/penaliterasi

Email : penaliterasi@umi.ac.id

Memahami karya sastra novel dengan mengenal dan memahami unsur instrinsik dan ekstrinsik. Semi (1988) menyatakan, bahwa struktur dalam (instrinsik) adalah unsur yang membentuk karya sastra seperti tokoh dan perwatakan, tema, alur, latar dan amanat. Menurut Esten (1993) menyatakan, unsur instrinsik sastra meliputi tema dan amanat, penokohan, latar, alur, dan pusat pengisahan.

Dari segi permasalahan tersebut, maka peneliti merasa perlu untuk melaksanakan penelitian tindakan kelas untuk meningkatkan keterampilan mengapresiasi novel siswa kelas IX SMPN 10 Payakumbuh. Dalam hal ini peneliti mengambil alternatif dengan menggunakan pendekatan kooperatif tipe think pair share. Pembelajaran kooperatif merupakan salah satu model pembelajaran kelompok sebagai upaya untuk meningkatkan prestasi belajar siswa dan upaya meningkatkan kemampuan sosial siswa.

Menurut Slavin (2005), pembelajaran kooperatif merujuk pada berbagai metode pengajaran dimana siswa belajar dalam kelompok-kelompok kecil untuk membantu satu sama lain dalam mempelajari materi pelajaran. Dalam kelas kooperatif para siswa diharapkan dapat saling membantu, saling mendiskusikan, dan beragumentasi untuk mengasah pengetahuan yang mereka kuasai pada saat itu dan

\section{PENA LITERASI}

Jurnal Pendidikan Bahasa dan Sastra Indoniasia Volume \& Nomor I April 2018

menutup kesenjangan dalam pemahaman masing-masing.

Sanjaya (2006) mengemukakan, empat prinsip dasar pembelajaran kooperatif, yaitu prinsip ketergantungan positif, tanggung jawab perseorangan, interaksi tatap muka, dan partisipasi dan komunikasi. Dengan demikian, pembelajaran kooperatif dapat membentuk karakter, nilai, dan norma kehidupan yang menjadi landasan berpikir dan bertindak.

Menurut Ibrahim dkk. (2005), terdapat enam langkah utama dalam pembelajaran kooperatif yaitu pembelajaran dimulai dengan guru menyampaikan tujuan pembelajaran dan memotivasi siswa. Kemudian penyajian informasi. Selanjutnya siswa dikelompokan dalam tiga tim belajar. Selanjutnya guru memberikan bimbingan pada saat siswa bekerja sama untuk menyelasaikan tugas bersama mereka. Fase terakhir terdiri dari evaluasi dan memberi penghargaan terhadap usaha-usaha kelompok maupun individu. Keunggulan dari think pair share ini adalah optimalisasi partisipasi siswa. Lie (2004) menyatakan, bahwa tipe think pair share dapat memberi kesempatan lebih banyak kepada siswa untuk dikenali dan menunjukan partisipasi mereka pada orang lain.

\section{METODE PENELITIAN}

enelitian ini tergolong pada penelitian tindakan kelas. Tindakan kelas yang 
e-ISSN : 2614-8226

Website : https://jurnal.umj.ac.id/index.php/penaliterasi

Email : penaliterasi@umi.ac.id

diberikan pada penelitian ini adalah penerapan pembelajaran kooperatif tipe think pair share. Menurut Arikunto (2006), penelitian tindakan kelas merupakan suatu pencermatan terhadap kegiatan belajar berupa sebuah tindakan, yang sengaja dimunculkan dan terjadi dalam Dindakan tersebut diberikan oleh guru atau arahan dari guru yang dilakukan oleh siswa.

Subjek penelitian ini adalah $\begin{array}{llll}\text { siswa kelas IX SMPN } 10 & \end{array}$ Payakumbuh yang berjumlah 30 orang. Data dalam penelitian ini berbentuk data kualitatif dan data kuantitatif. Data kuallitatif berupa tindakan guru, aktivitas siswa, dan tanggapan siswa selama proses pembelajaran. Data kuantitatif yaitu tes hasil belajar pada setiap akhir siklus.

Penganalisisan data pada penelitian ini dibagi menjadi data kualitatif dan data kuantitatif. Langkah-langkah yang akan dilakukan peneliti dalam menganalisis data tersebut adalah sebagi berikut. Data Kualitatif dianalisis dengan menggunakan analisis interaktif yang terdiri atas tiga komponen, yaitu: (1) reduksi data, (2) penyajian data, dan (3) pengambilan kesimpulan. Data kuantitatif dianalisis seperti langkahlangkah ini, yaitu: (a) pengelompokan data, (b) pemberian skor, (c) pengolahan nilai, (d) mencari ratarata, (e) menganalisis data yang sudah

\section{PENA LITERASI}

Jurnal Pendidikan Bahasa dan Sastra Indoniasia Volume $x$ Nomor 1 April 2018

disimpulkan, dan $\begin{array}{r}\text { (f) } \\ \text { menyimpulkan } \\ \text { pembahasan. }\end{array}$
hasil

\section{HASIL DAN PEMBAHASAN}

\section{Hasil Penelitian Siklus I \\ a. Perencanaan}

erencanaan dilakukan berdasarkan aspek aspek yang tidak terlaksana dalam pembelajaran prasiklus. Pada siklus 1 pembelajaran dilaksanakan menggunakan kooperatif tipe think pair share. Pembelajaran pada siklus 1 siswa akan dihadapkan langsung pada karya sastra berbentuk novel. Peneliti mempersiapkan perangkat pembelajaran berupa rencana pelaksanaan pembelajaran (RPP) yang berisi standar kompetensi, kompetensi dasar, indikator, materi pembelajaran, metode pembelajaran, sumber pembelajaran, dan penilaian. Penulis juga mempersiapkan lembaran observasi, catatan lapangan dan menyususn soal-soal untuk tes.

\section{b. Pelaksanaan}

telah $\begin{gathered}\text { Berdasarkan } \\ \text { disusun }\end{gathered} \begin{array}{r}\text { rencana yang } \\ \text { sebelumnya, }\end{array}$ penggunaan pembelajaran kooperatif tipe think pair share dalam pembelajaran membandingkan karakteristik novel angkatan 20-30an dilaksanakan dua kali pertemuan. Pertemuan pertama dilaksanakan 11 April dan pertemuan kedua dilaksanakan pada 13 April 2016. 
e-ISSN : 2614-8226

Website : https://jurnal.umj.ac.id/index.php/penaliterasi

Email : penaliterasi@umj.ac.id

c. Pengamatan dan Penilaian

a) Pengamatan aktivitas siswa dalam pembelajaran mengapresiasikan novel melalui pembelajaran kooperatif tipe think pair share

Hasil rekapitulasi yang menggambarkan taraf keberhasilan aktivitas siswa dalam pembelajaran kooperatif tipe think pair share dapat dilihat pada tabel berikut.

Tabel 1: Hasil observasi aktivitas siswa dalam pembelajaran

\begin{tabular}{|c|c|c|c|}
\hline \multirow{2}{*}{$\begin{array}{l}\mathrm{N} \\
\mathrm{O}\end{array}$} & \multirow{2}{*}{$\begin{array}{l}\text { Aktivitas } \\
\text { siswa }\end{array}$} & \multicolumn{2}{|l|}{ Siklus 1} \\
\hline & & $\begin{array}{l}\text { Pertem } \\
\text { uan } 1\end{array}$ & $\begin{array}{l}\text { Pertem } \\
\text { uan } 2\end{array}$ \\
\hline 1 & $\begin{array}{l}\text { Keserius } \\
\text { an dalam } \\
\text { membac } \\
\text { a novel }\end{array}$ & 3,19 & \\
\hline 2 & $\begin{array}{l}\text { Keserius } \\
\text { an siswa } \\
\text { dalam } \\
\text { mengerja } \\
\text { kan tugas } \\
\text { mandiri }\end{array}$ & & 3.00 \\
\hline 3 & $\begin{array}{l}\text { Kemaua } \\
\mathrm{n} \text { siswa } \\
\text { dalam } \\
\text { mengerja } \\
\text { kan tugas } \\
\text { kelompo } \\
\mathrm{k}\end{array}$ & & 3.19 \\
\hline 4 & $\begin{array}{l}\text { Kemaua } \\
\mathrm{n} \quad \text { siswa } \\
\text { berbagi } \\
\text { dengan } \\
\text { kelompo } \\
\mathrm{k} \text { lain }\end{array}$ & & 2.87 \\
\hline
\end{tabular}

\section{PENA LITERASI}

Jurnal Pendidikan Bahasa dan Sastra Indoniasia Volume $x$ Nomor 1 April 2018

\begin{tabular}{|l|l|l|l|}
\hline 5 & Suasana & 2,67 & \\
& hati & & \\
& siswa & & \\
& dalam & & \\
& PBM & & \\
\hline
\end{tabular}

Berdasarkan uraian di atas dapat disimpulkan bahwa penerapan pendekatan kooperatif tipe think pair share dapat dinilai cukup baik. Hal ini disebabkan siswa belum terbiasa berhadapan dengan novel secara utuh dan penerapan pembelajaran tipe ini masih perlu ditingkatkan, baik dari segi siswa maupun kreativitas guru dalam perencanaan, pelaksanaan, dan evaluasi.

b) Pengamatan aktivitas guru dalam pembelajaran

Berdasarkan hasil pengamatan yang dilakukan observer terhadap aktivitas guru selama siklus I adalah sebagai berikut. Guru telah menyusun RPP sesuai dengan model pembelajaran kooperatif tipe think pair share. Pelaksanaan pembelajaran yang dilakukan guru sesuai dengan langkah-langkah pembelajaran tipe think pair share. Namun, ada beberapa hal yang terjadi di luar perkiraan guru. Keluhan yang terjadi adalah adanya keluhan siswa tentang waktu yang diberikan terlalu singkat, sehingga ada beberapa orang yang belum bisa menamatkan membaca novel. Saat proses diskusi kelompok siswa belum memperlihatkan kemampuan yang maksimal, siswasiswa masih mengandalkan teman yang pandai dan aktif, sementara 
e-ISSN : 2614-8226

Website : https://jurnal.umj.ac.id/index.php/penaliterasi

Email : penaliterasi@umi.ac.id

siswa yang lain tidak banyak menyumbangkan saran dan pendapat hasil diskusi kelompoknya.

c) Hasil tes unjuk kerja siklus 1

Tabel 2: rekapitulasi hasil tes mengapresiasi novel perindikator

\begin{tabular}{|l|l|l|}
\hline No & Indikator & Nilai \\
\hline 1 & Menentukan tema & 70,97 \\
\hline 2 & $\begin{array}{l}\text { Menentukan dan } \\
\text { tokoh } \\
\text { penokohan }\end{array}$ & 67,74 \\
\hline 3 & Menentukan latar & 67,74 \\
\hline 4 & Menentukan alur & 70,79 \\
\hline 5 & $\begin{array}{l}\text { Menentukan sudut } \\
\text { pandang }\end{array}$ & 66,13 \\
\hline 6 & $\begin{array}{l}\text { Menentukan } \\
\text { amanat }\end{array}$ & 66,94 \\
\hline 7 & $\begin{array}{l}\text { Menentukan gaya } \\
\text { bahasa }\end{array}$ & 69,35 \\
\hline 8 & $\begin{array}{l}\text { Menentukan nilai } \\
\text { etika }\end{array}$ & 67,74 \\
\hline 9 & $\begin{array}{l}\text { Menentukan nilai } \\
\text { moral }\end{array}$ & 73,39 \\
\hline & Rata-rata & 68,99 \\
\hline
\end{tabular}

\section{d. Refleksi}

Berdasarkan hasil pembelajaran yang diperoleh pada siklus 1 dapat disimpulkan bahwa minat baca siswa terhadap novel sudah mulai cukup baik, walaupun masih ada siswa yang belum mampu menamatkan sebuah novel dalam waktu yang sudah ditetapkan. Aktivitas yang dilakukan siswa dalam pembelajaran masih terlihat kaku ketika mereka berbagi dengan kelompok lain. Mereka masih belum mampu berinteraksi satu sama lain. Walaupun masih terdapat

\section{PENA LITERASI}

Jurnal Pendidikan Bahasa dan Sastra Indoniasia Volume \& Nomor I April 2018

kekurangan dan kelemahan tindakan perbaikan pembelajaran perlu dilanjutkan pada siklus II peneliti memberikan waktu dua minggu untuk menyelesaikan bacaan novel dan mencari unsur instrinsik dan nilai moral, nilai etika, dan nilai adat. Untuk meningkatkan aktivitas siswa perlu variasi dan teknik pembelajaran. Variasi tersebut direncanakan sebagai berikut. Siswa membuka tugas rumahnya dan mendiskusikan dengan teman sebangku tentang unsur instrinsik dan nilai-nilai yang terkandung dalam novel yang sama. Setelah itu siswa mencari pasangan dengan novel yang berbeda dan membandingkan unsur instrinsik dan nilai dengan bukti tekstual. Kemudian dilanjutkan dengan berbagi dengan kelompok lain.

\section{Hasil Penelitian Siklus II}

\section{a. Perencanaan}

Proses yang dilaksanakan pada siklus II ini memaksimalkan peningkatan pemahaman siswa terhadap novel dan peningkatan aktivitas siswa dalam pembelajaran kooperatif. Novel yang akan dibaca pada siklus II berbeda dengan siklus I. Adanya keterbatasan novel angkatan 20-30-an, peneliti memberikan beberapa judul novel angkatan 20-30-an dan siswa boleh membaca salah satu dari novel tersebut. 
e-ISSN : 2614-8226

Website : https://jurnal.umj.ac.id/index.php/penaliterasi

Email : penaliterasi@umi.ac.id

\section{b. Pelaksanaan}

Berdasarkan rencana yang telah disusun sebelumnya, penggunaan pembelajaran kooperatif tipe think pair share dalam pembelajaran membandingkan karakteristik novel angkatan 20-30an dilaksanakan dua kali pertemuan. Pertemuan pertama dilaksanakan pada 2 Mei dan pertemuan kedua dilaksanakan pada 4 Mei 2016.

c. Pengamatan dan penilaian

a) Pengamatan aktivitas siswa dalam pembelajaran dalam mengapresiasikan novel

Berdasarkan hasil pengamatan dapat dilihat bahwa aktivitas belajar siswa sudah meningkat. Hasil rekapitulasi observasi siswa dapat dilihat pada tabel berikut.

Tabel 3. Hasil rekapitulasi aktivitas siswa dalam pembeljaran

\begin{tabular}{|l|l|l|l|}
\hline N & Aktivitas & \multicolumn{2}{|l|}{ Siklus II } \\
\cline { 3 - 4 } o & siswa & $\begin{array}{l}\text { Perte } \\
\text { muan } \\
1\end{array}$ & $\begin{array}{l}\text { Perte } \\
\text { muan 2 }\end{array}$ \\
\hline 1 & $\begin{array}{l}\text { Keseriusan } \\
\text { siswa } \\
\text { membaca } \\
\text { novel }\end{array}$ & 4,13 & 4,10 \\
\hline 2 & $\begin{array}{l}\text { keseriusan } \\
\text { siswa } \\
\text { mengerjaka } \\
\mathrm{n} \text { tugas } \\
\text { mandiri }\end{array}$ & & \\
\hline
\end{tabular}

\section{PENA LITERASI}

Jurnal Pendidikan Bahasa dan Sastra Indoniasia

Volume 1 Nomor 1 April 2018

\begin{tabular}{|l|l|l|l|}
\hline 3 & $\begin{array}{l}\text { Keseriusan } \\
\text { siswa dalam } \\
\text { mengerjaka } \\
\mathrm{n} \mathrm{tugas} \\
\text { kelompok }\end{array}$ & & 4,13 \\
\hline 4 & $\begin{array}{l}\text { Keseriusan } \\
\text { siswa } \\
\text { berbagi } \\
\text { dengan } \\
\text { kelompok } \\
\text { lain }\end{array}$ & & 4,29 \\
\hline 5 & $\begin{array}{l}\text { Suasana hati } \\
\text { dalam } \\
\text { pembelajara } \\
\text { n }\end{array}$ & & \\
\hline
\end{tabular}

Berdasarkan tabel 3 dapat disimpulkan bahwa aktivitas siswa pada siklus II penerapan pendekatan kooperatif tipe think pair share mengalami peningkatan bila dibandingkan pada siklus I sudah dinilai baik. Hal ini disebabkan siswa terbiasa berhadapan dengan penerapan pembelajaran kooperatif tipe think pair share.

b) Pengamatan aktivitas guru

Berdasarkan hasil pengamatan yang dilakukan observer terhadap aktivitas guru dalam pembelajaran kooperatif tipe think pair share terlaksana dengan baik. Hasil pengamatan yang dilakukan adalah sebagai berikut. Pertama guru telah menyusun rencana pelaksanaan pembelajaran sesuai dengan model pembelajaran kooperatif tipe think pair share. Kedua, pelaksanaan 
e-ISSN : 2614-8226

Website : https://jurnal.umj.ac.id/index.php/penaliterasi

Email : penaliterasi@umj.ac.id

pembelajaran yang dilakukan guru sesuai dengan ketaatan guru dalam langkah-langkah pembelajaran kooperatif tipe think pair share yang dilaksanakan dalam dua kali pertemuan.

c) Hasil tes unjuk kerja

Tabel 4: Rekapitulasi hasil tes mengapresiasi novel perindikator

\begin{tabular}{|l|l|l|}
\hline No & Indikator & Nilai \\
\hline 1 & $\begin{array}{l}\text { Menentukan } \\
\text { tema }\end{array}$ & 79,35 \\
\hline 2 & $\begin{array}{l}\text { Menentukan } \\
\text { tokoh } \\
\text { penokohan }\end{array}$ & 76,61 \\
\hline 3 & $\begin{array}{l}\text { Menentukan } \\
\text { latar }\end{array}$ & 75,81 \\
\hline 4 & Menentukan alur & 75,81 \\
\hline 5 & $\begin{array}{l}\text { Menentukan } \\
\text { sudut pandang }\end{array}$ & 76,61 \\
\hline 6 & $\begin{array}{l}\text { Menentukan } \\
\text { amanat }\end{array}$ & 80,65 \\
\hline 7 & $\begin{array}{l}\text { Menentukan } \\
\text { gaya bahasa }\end{array}$ & 80,65 \\
\hline 8 & $\begin{array}{l}\text { Menentukan } \\
\text { nilai etika }\end{array}$ & 83,06 \\
\hline 9 & $\begin{array}{l}\text { Menentukan } \\
\text { nilai moral }\end{array}$ & 85,48 \\
\hline & Rata-rata & 79,22 \\
\hline
\end{tabular}

Berdasarkan tabel di atas setiap indikator penilaian sudah mencapai kriteria ketuntasan minimal.secara umum perolehan nilai untuk setiap indikator sudah meningkat bila dibandingkan pada siklus I.

\section{PENA LITERASI}

Jurnal Pendidikan Bahasa dan Sastra Indoniasia

Volume 1 Nomor 1 April 2018

\section{d. Refleksi}

Berdasarkan hasil catatan dilapangan dapat disimpulkan bahwa siswa sudah mampu mencatat dan mengambil kesimpulan sendiri tentang pembelajaran. Siswa mulai merefleksi kebermaknaan dalam pembelajaran sastra dan menemukan nilai yang terkandung dalam sastra. Sikap siswa dalam dalam menerima pendapat orang lain dengan baik dan sudah bisa menerima kesalahan yang dikemukakan kelompok lain. Saling harga menghargai pendapat orang lain dalam diskusi sudah terlihat baik. Perlu diperhatikan adalah beberapa orang siswa yang masih belum mau untuk mempresentasikan hasil kerjanya ke depan kelas padahal hasil kerjanya baik. Secara keseluruhan pada siklus II ini pembelajaran kooperatif tipe think pair share dinilai berhasil dengan baik.

\section{KESIMPULAN}


e-ISSN : 2614-8226

Website : https://jurnal.umj.ac.id/index.php/penaliterasi

Email : penaliterasi@umj.ac.id

Bembahasan dapat disimpulkan, pertama, proses peningkata keterampilan mengapresiasikan novel mengalami peningkatan setelah menggunakan pembelajaran kooperatif tipe think pair share. Keantusisasan siswa terhadap mengapresiasikan novel dapat dilihat dari kerja keras siswa dalam membaca novel dan tugas-tugas yang diberikan. Kedua, berdasarkan tindakan yang diberikan dalam mengapresiasikan novel dapat dinilai berhasil dengan baik. Hal ini terlihat dari hasil yang diperoleh siswa dalm proses pembelajaran maupun dalam tes akhir siklus. Ketiga, faktor-faktor terjadinya peningkatan dalam mengapresiasikan novel tidak terlepas dari pemilihan model pembelajaran yang sesuai dengan materi dan karakteristik siswa. Perencanaan yang matang dalam proses pembelajaran sangat berarti dalam keberhasilan siswa. Hubungan sesama siswa harus harus terjalin dengan baik karena manusia hidup saling membutuhkan.

\section{Referensi}

Aminuddin. 2009. Pengantar Apresiasi Karya Sastra. Bandung: Sinar Baru Algesindo.

Arikunto, Suharsimi dkk. 2007. Penelitian Tindakan Kelas. Jakarta: Bumi Aksara.

\section{PENA LITERASI}

Jurnal Pendidikan Bahasa dan Sastra Indoniasia Volume I Nomor I April 2018

Esten, Mursal. 1988. Menjelang Teori dan Kritik Susastra Indonesia Yang Relevan. Bandung: Angkasa.

Ibrahim, Muslimin dkk. 2005. Pembalajaran Kooperatif. Surabaya: UNESAUniversity Press.

Kurniawan, Heru. 2009. Sastra Anak Dalam Kajian Strukturalisme, Sosiologi, Semiotika, Hingga Penulisan Kreatif. Yogyakarta: Graha Ilmu.

Lie, Anita. 2002. Cooperative Learning Mempraktikkan Kooperatif di Ruang-Ruang Kelas. Jakarta: Grasindo.

Sanjaya, Wina. 2006. Penelitian Tindakan Kelas. Jakarta: Kencana Prenada Media Group.

Semi, M. Atar. 1988. Anatomi Sastra. Padang: Angkasa Raya.

Slavin, Robert E. 2005. Cooperative Learning Teori, Riset dan Praktik. Bandung: Nusa Media.

Waluyo, Herman J. 2002. Apresiasi Puisi Untuk Pelajar dan Mahasiswa. Jakarta: Gramedia Pustaka. 
e-ISSN : 2614-8226

Website : https:/jurnal.umj.ac.id/index.php/penaliterasi

Email : penaliterasi@umj.ac.id
PENA LITERASI

Jurnal Pendidikan Bahasa dan Sastra Indoniasia Volume 1 Nomor 1 April 2018 